\title{
Inheritance of Resistance in Melon PI 313970 to Cucurbit Powdery Mildew Incited by Podosphaera xanthii Race S
}

\author{
James D. McCreight ${ }^{1}$ \\ U.S. Department of Agriculture, Agricultural Research Service, U.S. \\ Agricultural Research Station, 1636 E. Alisal Street, Salinas, CA 93905
}

\author{
Michael D. Coffey \\ University of California, Department of Plant Pathology, 3206 Webber Hall, \\ Riverside, CA 92521
}

Additional index words. Cucumis melo, Sphaerotheca fuliginea, resistant blister

\begin{abstract}
A new strain of cucurbit powdery mildew incited by Podosphaera xanthii (Castagne) Braun \& Shishkoff (formerly Sphaerotheca fuliginea), designated race $\mathrm{S}$, is virulent on all the commonly used melon (Cucumis melo $\mathrm{L}$.) powdery mildew race differentials and first appeared on melon in Yuma, AZ, and Imperial Valley, CA, in 2003. Melon PI 313970 (C. melo var. acidulus) was resistant to $P$. xanthii race $S$ in 2003 and subsequent years. Inheritance of resistance to $P$. xanthii race $S$ was studied in two naturally infected, replicated field tests in Imperial Valley in 2005 and 2009 using the parents and $F_{1}, F_{2}$, and reciprocal backcross generations from crosses of PI 313970 with powdery mildew-susceptible 'Top Mark'. Resistance to race $S$ was recessive: all $F_{1}$ and $\mathrm{BC}_{\mathrm{TM}}$ individuals were susceptible. One recessive gene, designated $\mathrm{pm}-\mathrm{S}$, conditioned resistance to race $S$ in the $F_{2}$ and $B C_{P I}$. The relationship of $p m-S$ to the previously reported recessive and codominant genes in $P I 313970$ for resistance to $P$. xanthii races 1 , 2, 2U.S., 3, 3.5, 4.5, and 5 remains to be determined.
\end{abstract}

Cucurbit powdery mildew (CPM), a major problem of melon (Cucumis melo L.) production worldwide, is mostly caused by two fungi: Podosphaera xanthii and Golovinomyces cichoracearum (DC) V.P. Heluta (formerly Erysiphe cichoracearum) (Jahn et al., 2002). Infection may be by either pathogen alone or it may be a coinfection of the two species (Kř́stková et al., 2009). Only $P$. xanthii has been found on melon in the United States (Kable and Ballantyne, 1963; McCreight, 2004), although a strain of $G$. cichoracearum isolated from Arabidopsis thaliana (L.) Heynh. was able to infect cucurbits, including melon (Adam et al., 1999). CPM has been successfully controlled by applications of fungicides (McGrath, 2001)

\footnotetext{
Received for publication 28 Jan. 2011. Accepted for publication 8 Apr. 2011

Funded in part by a grant from the California Melon Research Board.

We thank Patti Fashing for assistance in the field tests.

USDA is an equal opportunity provider and employer.

Mention of trade names or commercial products in this publication is solely for the purpose of providing specific information and does not imply recommendation or endorsement by the U.S. Department of Agriculture.

${ }^{1}$ To whom reprint requests should be addressed; e-mail jim.mccreight@ars.usda.gov.
}

and genetic, host plant resistance (McCreight, 2006).

The first successful scientific effort in the United States to breed melons for resistance to CPM culminated in the release of 'PMR 45' in 1935 (Jagger and Scott, 1937). A new physiological race of $P$. xanthii, race 2 , emerged within a few years in the Imperial Valley (Jagger et al., 1938), the original strain then being designated race 1 . Race 3 of $P$. xanthii was first observed in the lower Rio Grande Valley of Texas in 1977 (Thomas, 1978). Seven races of $P$. xanthii were known on melon in 1998 (Pitrat et al., 1998), but the number of reported races may be as many 28 (McCreight, 2006) or more (Coffey et al., 2006; Pitrat and Besombes, 2008). Physiological races of CPM may also be defined by sensitivity to fungicides (McGrath and Staniszewska, 1996).

The CPM situation on melons can be dynamic. Race 1 of $P$. xanthii was replaced by race 2 in Imperial Valley shortly after release and widespread planting of 'PMR 45' (Jagger et al., 1938). Occurrence of race 1 in Imperial Valley after many years of no commercial plantings of 'PMR 45', susceptible to race 2, or 'Top Mark', which is susceptible to $P$. xanthii races 1 and 2 (Pitrat et al., 1998), would not be expected, but its appearance there in 2001 (McCreight, 2002) was surprising given the virtually complete replacement of 'PMR 45' and 'Top Mark' by race 1 and race 2-resistant hybrid melon cultivars. The
CPM race situation changed dramatically in the Imperial Valley and Yuma after the turn of the 21st century. Commercial melon fields planted in Spring 2003 with cultivars possessing resistance to either or both races 1 and 2 suffered high levels of infection and yield losses (T.A. Turini, Univ. Calif. Coop. Ext., unpublished data). A replicated planting at the University of California, Desert Research and Education Center (DREC), Holtville, CA, of commonly used $P$. xanthii race differentials clearly indicated a new race, designated $\mathrm{S}$, in the Imperial Valley to which melon accession PI 313970 was highly resistant (Coffey et al., 2006; McCreight et al., 2005).

Melon accession PI 313970 is a source of potentially unique genes for resistance to CPM in the United States and Europe (McCreight, 2003; Pitrat and Besombes, 2008). PI 313970 also exhibits non-race-specific resistance that is manifested by resistant blisters (McCreight, 2003; Sedlářová et al., 2009). Our objective was to determine the inheritance of race specific and non-race-specific resistances to $P$. xanthii race S in PI 313970.

\section{Materials and Methods}

Two naturally infected field tests were planted at DREC in 2005 and 2009. The fields were watered using subsurface drip irrigation for germination and subsequently as needed. Imidacloprid for control of sweetpotato whitefly was sprayed at the label rate along the seed line immediately after the initial irrigation.

The 2005 field test was planted on 2 Mar. and consisted of randomized complete blocks (RCB) with seven replications of the susceptible 'Top Mark' (TM), PI 313970 (PI), and their $\mathrm{F}_{1}, \mathrm{~F}_{2}$, and backcross generations. Each replication included one plot of each parent, one plot of each reciprocal $F_{1}$, five plots of their $F_{2}$, one plot of the backcross of the $F_{1}$ to 'Top Mark' $\left(\mathrm{BC}_{\mathrm{TM}}\right)$, and two plots of the backcross of the $\mathrm{F}_{1}$ to PI 313970 (BC $\mathrm{BI}_{\mathrm{PI}}$ ). Six seeds were individually planted in each plot at a spacing of $1.5 \mathrm{~m}$ on flat beds spaced on 2.0-m centers. The 2009 experiment was planted on 1 Apr. and was identical to the 2005 experiment with the following exceptions: hills spaced $1.8 \mathrm{~m}$, six replications, one $\mathrm{F}_{1}$ progeny $(\mathrm{TM} \times \mathrm{PI})$, one plot of $\mathrm{BC}_{\mathrm{TM}}$, three plots of $\mathrm{BC}_{\mathrm{PI}}$, and different $\mathrm{F}_{1}, \mathrm{~F}_{2}$, and backcross progenies. Emergence rates ranged from $32 \%\left(\mathrm{BC}_{\mathrm{TM}}\right)$ to $76 \%\left(\mathrm{~F}_{2}\right.$ and $\left.\mathrm{BC}_{\mathrm{PI}}\right)$ in 2005 and from $55 \%$ (TM) to $88 \%$ (PI) in 2009 and, thus, reduced the number of plants evaluated for PM. Guard plots and border rows were planted with $P$. xanthii-susceptible 'Golden Beauty Casaba'.

Presence of race $\mathrm{S}$ was verified in adjacent, replicated plantings of the CPM differentials (Pitrat et al., 1998) and PI 313970 (Table 1) that were planted on the same dates as the genetic studies. The differentials were planted in a RCB design with three replications. Plots were $3.6 \mathrm{~m}$ (2005) or $4.6 \mathrm{~m}$ (2009) long on $2.0-\mathrm{m}$ wide beds and consisted of three hills spaced $1.2 \mathrm{~m}$ apart with two seeds per hill and one $P$. xanthii race differential per plot. Poor emergence reduced the numbers of 
plants per entry; mean numbers of plants per plot ranged from two to four in 2005 and two to five in 2009. Disease evaluations were done on a plot basis.

CPM infection severity was evaluated once, when fruit of TM were mature: 22 June in 2005 and 17 June in 2009. Infection as evidenced by mycelial growth and sporulation was evaluated on true leaves using a 1 to 9 scale as follows: $1=$ no evidence of disease; 2 , trace of hyphae, no detectable sporulation; 3 , hyphae restricted, no detectable sporulation; 4, few colonies present, sporulation; 5, scattered colonies, sporulation; 6 , numerous colonies, sporulation; $7, \approx 50 \%$ of adaxial surface covered with hyphae and spores, few colonies on abaxial surface, abundant sporulation; 8 , greater than $50 \%$ of adaxial surface covered with hyphae and spores, scattered colonies on abaxial surface, abundant sporulation; and 9 , greater than $75 \%$ of adaxial surface covered with hyphae and spores, numerous or coalesced colonies on the abaxial surface.

Mean (race differential) or individual plant (genetic study) disease rating less than 4.0 was considered resistant and a respective rating 4.0 or greater was considered susceptible. Nonrace-specific resistance was evaluated as presence or absence of resistant blisters. Segregation data from the $\mathrm{F}_{2}, \mathrm{BC}_{\mathrm{TM}}$, and $\mathrm{BC}_{\mathrm{PI}}$ were subjected to chi-square analyses.

\section{Results and Discussion}

In both tests, $P$. xanthii race $\mathrm{S}$ was present as indicated by the susceptible reactions on all the commonly used $P$. xanthii race differentials and the resistant reaction of PI 313970 (Table 1). In 2009, infection of the differentials was not uniform across the three replications, although the surrounding guards and border rows ('Golden Beauty Casaba') were observed to be heavily and uniformly infected (data not shown).

Infection of basal internodes was observed on two individuals of PI 313970 in 2009 , although they exhibited no evidence of foliar infection other than some possible hypersensitive reactions (Sedlárová et al., 2009), and a small, restricted infection was noted on the crown of one $\mathrm{BC}_{\mathrm{PI}}$ individual. A similar reaction was observed that year in a nonreplicated test of the $P$. xanthii race differen-

Table 1. Reactions of cucurbit powdery mildew race differentials including PI 313970 to $P$. xanthii race $\mathrm{S}$ in naturally infected field tests, Holtville, CA, June 2005 and 2009. ${ }^{\text {}}$

\begin{tabular}{lcc}
\hline Differential & 2005 & 2009 \\
\hline Iran H & $\mathrm{S}$ & $\mathrm{S}$ \\
Védrantais & $\mathrm{S}$ & $\mathrm{S}$ \\
Top Mark & $\mathrm{S}$ & $\mathrm{S}$ \\
PMR 45 & $\mathrm{S}$ & $\mathrm{S}$ \\
PMR 5 & $\mathrm{S}$ & $\mathrm{S}$ \\
WMR 29 & $\mathrm{S}$ & $\mathrm{S}$ \\
Edisto 47 & $\mathrm{S}$ & $\mathrm{S}$ \\
PI 414723 & $\mathrm{S}$ & $\mathrm{S}$ \\
MR-1 & $\mathrm{S}$ & $\mathrm{S}$ \\
PI 124111 & $\mathrm{S}$ & $\mathrm{S}$ \\
PI 124112 & $\mathrm{S}$ & $\mathrm{S}$ \\
PI 313970 & $\mathrm{R}$ & $\mathrm{R}$ \\
\hline
\end{tabular}

${ }^{\mathrm{z}} \mathrm{S}=$ susceptible; $\mathrm{R}=$ resistant. tials at the University of Arizona, Yuma Agricultural Research Center, $\approx 70 \mathrm{~km}$ to the east of DREC (data not shown). This difference between foliage and basal internodes on a few plants of PI 313970 at these two sites may have been the result of chance alone or heterogeneity for virulence factors in the CPM populations. Three known $P$. xanthii races are virulent on PI 313970. Race $\mathrm{F}$, originally designated Isolate Px 61/02, was isolated in the Czech Republic (Lebeda and Sedláková, 2004; Sedlárová et al., 2009). Race SD was isolated from Yuma and the Imperial Valley (Coffey et al., 2006) and occurs in a greenhouse at Salinas where PI 313970 has been grown since the early 1990s (McCreight, unpublished data). Race SDW is, like race $\mathrm{SD}$, virulent on PI 313970 and also on 'Crimson sweet' watermelon, Citrullus lanatus (Thunb.) Matsum \& Nakai (Coffey et al., 2006). The commonly used race differentials were susceptible in both years, like in 2003, when race S was first observed (Coffey et al., 2006; McCreight et al., 2005), and PI 313970 was clearly resistant in both years (Tables 1 and 2).

All 'Top Mark' plants were infected in 2005 , but there were two escapes in 2009 (Table 2). The reciprocal $F_{1}$ progenies were susceptible (Table 2), a clear indication that resistance to $P$. xanthii race $\mathrm{S}$ in PI 313970 is genetically recessive. The $\mathrm{F}_{2}$ families segregated in acceptable fits to the expected 3 susceptible: 1 resistant ratio, and the $\mathrm{BC}_{\mathrm{TM}}$ families were susceptible with the exception of one escape in 2009 (Table 2). The $\mathrm{BC}_{\mathrm{PI}}$ families segregated in acceptable fits to the expected 1 susceptible: 1 resistant ratio in 2005 and 2009 (Table 2).

These results from two seasons clearly indicate a single, recessive gene, designated $p m-S$, for resistance to race S in PI 313970. Further studies are needed to determine allelism with the previously reported eight genes in PI 313970 for resistance to six races of $P$. xanthii (McCreight, 2003; Pitrat and Besombes, 2008).

Resistant blisters were readily observed on 19 of the 22 plants of PI 313970 in 2005 but none was evident in 2009. The discrepancy in expression of this trait between the 2

Table 2. Race-specific reactions of 'Top Mark', PI 313970, and their offspring to $P$. xanthii race S in naturally infected field tests, Holtville, CA, June 2005 and 2009.

\begin{tabular}{|c|c|c|c|c|c|}
\hline \multirow[b]{2}{*}{ Entry } & \multicolumn{2}{|c|}{ Observed } & \multirow[b]{2}{*}{ Expected ratio } & \multirow[b]{2}{*}{$\chi^{2}$} & \multirow[b]{2}{*}{$P$} \\
\hline & Susceptible & Resistant & & & \\
\hline \multicolumn{6}{|c|}{ June 2005} \\
\hline Top Mark (TM) & 15 & 0 & & & \\
\hline PI 313970 (PI) & 0 & 22 & & & \\
\hline $\mathrm{F}_{1} \mathrm{TM} \times \mathrm{PI}$ & 31 & 0 & & & \\
\hline $\mathrm{F}_{1} \mathrm{PI} \times \mathrm{TM}$ & 29 & 0 & & & \\
\hline $\mathrm{F}_{2} \mathrm{TM} \times \mathrm{PI}$ & 127 & 32 & $3: 1$ & 2.01 & 0.16 \\
\hline $\mathrm{BC}_{\mathrm{TM}}(\mathrm{TM} \times \mathrm{PI}) \mathrm{TM}$ & 27 & 0 & & & \\
\hline $\mathrm{BC}_{\mathrm{PI}}(\mathrm{TM} \times \mathrm{PI}) \mathrm{PI}$ & 28 & 36 & $1: 1$ & 1.00 & 0.32 \\
\hline \multicolumn{6}{|c|}{ June 2009} \\
\hline Top Mark (TM) & 18 & 2 & & & \\
\hline PI 313970 (PI) & 0 & 32 & & & \\
\hline $\mathrm{F}_{1} \mathrm{TM} \times \mathrm{PI}$ & 26 & 0 & & & \\
\hline $\mathrm{F}_{2} \mathrm{TM} \times \mathrm{PI}$ & 102 & 38 & $3: 1$ & 0.24 & 0.64 \\
\hline $\mathrm{BC}_{\mathrm{TM}}(\mathrm{TM} \times \mathrm{PI}) \mathrm{TM}$ & 21 & 1 & & & \\
\hline $\mathrm{BC}_{\mathrm{PI}}(\mathrm{TM} \times \mathrm{PI}) \mathrm{PI}$ & 50 & 34 & $1: 1$ & 3.05 & 0.08 \\
\hline
\end{tabular}

years indicates some unknown environmental factor(s) affecting expression or penetrance of the resistant blister reaction. In 2005, neither the $F_{1}$ nor the $\mathrm{BC}_{\mathrm{TM}}$ exhibited resistant blisters, which suggested recessive control of this trait and was consistent with results with $P$. xanthii race 2 in a greenhouse (McCreight, 2003). The $\mathrm{F}_{2}$ and $\mathrm{BC}_{\mathrm{PI}}$ data did not, however, fit any simple Mendelian model (data not shown), which was also consistent with the greenhouse study (McCreight, 2003).

The resistant blister reactions of hops (Humulus lupulus L.) to hops powdery mildew incited by Podosphaera macularis (formerly $S$. humuli) is non-race-specific and controlled by a single dominant gene (Royle, 1978). Inheritance of resistant blisters to $P$. xanthii in melon PI 313970 is not clear. These race $S$ data and previous results with race 2 (McCreight, 2003) indicated recessive control of resistant blister in melon. Controlled inoculation studies under conditions that favor development of resistant blister may help clarify genetic control and expression of this resistance mechanism to CPM.

Melon PI 313970 is proving to be a rich source of genes for resistance to $P$. xanthii. Resistance in this accession to CPM is imparted by three different mechanisms: reduced conidial germination and appressorium formation, hypersensitive response, and resistant blisters, a non-race-specific response (Sedlářová et al., 2009). Non-race-specific (horizontal) resistance provides low to moderate levels of resistance in the face of new races of a pathogen and enhances race-specific (vertical) resistance (Vanderplank, 1968). The potential role of the non-race-specific mechanism exhibited as resistant blisters for control of CPM on melon is unknown.

These data demonstrate recessive resistance to $P$. xanthii race S in PI 313970 on whole plants under field conditions in response to natural infection. Deployment of recessive genes regardless of their race specificity poses a challenge to melon breeders as the industry continues to favor $\mathrm{F}_{1}$ hybrid cultivars, and their deployment will have to be done over some extended period because both parents must be homozygous for these alleles. Tightly linked 
molecular markers will facilitate deployment of recessive genes in the control of cucurbit powdery mildew of melon. Further research is needed to determine the relationship of $\mathrm{pm}-\mathrm{S}$ to the recessive and codominant genes in PI 313970 that control resistances to $P$. xanthii races 1, 2, 2U.S., 3, 3.5, 4.5, and 5 (McCreight, 2003; Pitrat and Besombes, 2008).

\section{Literature Cited}

Adam, L., S. Ellwood, I. Wilson, G. Saenz, S. Xiao, R.P. Oliver, J.G. Turner, and S. Somerville. 1999. Comparison of Erysiphe cichoracearum and E. cruciferarum and a survey of $360 \mathrm{Arabi}$ dopsis thaliana accessions for resistance to these two powdery mildew pathogens. Mol. Plant Microbe Interact. 12:1031-1043.

Coffey, M.D., J.D. McCreight, and T. Miller. 2006. New races of the cucurbit powdery mildew Podosphaera xanthii present in California. Phytopathology 96:S25 (abstr.).

Jagger, I.C. and G.W. Scott. 1937. Development of powdery mildew resistant cantaloup No. 45 . USDA Circ. 441:6.

Jagger, I.C., T.W. Whitaker, and D.R. Porter. 1938. A new biologic form of powdery mildew on muskmelons in the Imperial Valley of California. Plant Dis. Rptr. 22:275-276.

Jahn, M., H.M. Munger, and J.D. McCreight. 2002. Breeding cucurbit crops for powdery mildew resistance, p. 239-248. In: Bélanger, R.R., W.R. Bushnell, A.J. Dik and T.L.W. Carver (eds.). The powdery mildews: A comprehensive treatise. APS Press, St. Paul, MN.

Kable, F.P. and J.B. Ballantyne. 1963. Observation on the cucurbit powdery mildew in the Ithaca district. Plant Dis. Rptr. 47:482.

Křístková, E., A. Lebeda, and B. Sedláková. 2009. Species spectra, distribution and host range of cucurbit powdery mildews in the Czech Republic, some other European and middle Eastern countries. Phytoparasitica 37:337-350.

Lebeda, A. and B. Sedláková. 2004. Disease impact and pathogenicity variation in Czech populations of cucurbit powdery mildews, $\mathrm{p}$. 281-287. In: Lebeda, A. and H. Paris (eds.). Progress in cucurbit genetics and breeding research. Palacky University in Olomouc, Olomouc, Czech Republic.

McCreight, J.D. 2002. Powdery mildew race 1 in Imperial Valley, California. Cucurbit Genet. Coop. Rpt. 25:20-21.

McCreight, J.D. 2003. Genes for resistance to powdery mildew races 1 and 2U.S. in melon PI 313970. HortScience 38:591-594.

McCreight, J.D. 2004. Notes on the change of the causal species of cucurbit powdery mildew in the U.S. Cucurbit Genet. Coop. Rpt. 27:8-23.

McCreight, J.D. 2006. Melon-powdery mildew interactions reveal variation in melon cultigens and Podosphaera xanthii races 1 and 2. J. Amer. Soc. Hort. Sci. 131:59-65.

McCreight, J.D., M.D. Coffey, T.A. Turini, and M.E. Matheron. 2005. Field evidence for a new race of powdery mildew on melon. HortScience 40:888 (abstr.).
McGrath, M.T. 2001. Fungicide resistance in cucurbit powdery mildew: Experiences and challenges. Plant Dis. 85:236-245.

McGrath, M.T. and H. Staniszewska. 1996. Management of powdery mildew in summer squash with host resistance, disease threshold-based fungicide programs, or an integrated program. Plant Dis. 80:1044-1052.

Pitrat, M. and D. Besombes. 2008. Inheritance of Podosphaera xanthii resistance in melon line '90625', p. 135-142. In: Pitrat, M. (ed.). Cucurbitaceae 2008, IXth EUCARPIA Meeting on Genetics and Breeding of Cucurbitaceae. INRA, Avignon, France.

Pitrat, M., C. Dogimont, and M. Bardin. 1998. Resistance to fungal diseases of foliage in melon, p. 167-173. In: McCreight, J.D. (ed.). Cucurbitaceae '98: Evaluation and enhancement of cucurbit germplasm. ASHS Press, Alexandria, VA.

Royle, D.J. 1978. Powdery mildew of the hop, p. 381-409. In: Spencer, D.M. (ed.). The powdery mildews. Academic Press, New York, NY.

Sedlářová, M., A. Lebeda, P. Mikšíková, M. Duchoslav, B. Sedláková, and J.D. McCreight. 2009. Histological aspects of Cucumis melo PI 313970 resistance to Podosphaera xanthii and Golovinomyces cichoracearum. J. Plant Dis. Prot. 116:169-176.

Thomas, C.E. 1978. A new biological race of powdery mildew of cantaloups. Plant Dis. Rptr. 62:223.

Vanderplank, J.E. 1968. Disease resistance in plants. Academic Press, NY. 